\title{
INVESTIGATING THE NEED TO REDESIGN AMOL'S HEFDAHE SHAHRIVAR SQUARE WITH EMPHASIS ON THE PROMOTION OF FUNCTIONAL COMPONENTS
}

\author{
Ebrahim Amir Kalayi \\ Faculty member of archeology, Islamic Azad University, Savadkooh, Iran \\ Niki Amiri \\ Master in architecture, Islamic Azad University, Babol, Iran \\ Nik.amiri@yahoo.com
}

\begin{abstract}
17 Shahrivar square is considered one of the most important squares of Amol, which has four entrances from the streets of Emam Reza, Taleb Amoli, Sheikh Fazlolah Noori and Emam Khomeini. This study has been done with the aim of investigating the physical problems of Amol's 17 Shahrivar square to provide the causes of promoting functional components using its redesign. In this regard, a main and seven sub-hypothesis was considered which consists of (rhythm and balance, statics and dynamics, form and decoration, streets and pedestrian route, human activities, campaigns and social activities). Due to the high volume of population, Cochran's formula of unlimited population is used that the sample size of 196 individuals was selected. Collecting data was done using questionnaire and also books and articles. The SPSS software was used to analyze the data. Results obtained indicate that all components of research are in unfavorable condition and a sever need of redesign is felt in this square.
\end{abstract}

Keywords: square, redesign, physical problems, functional components.

\section{INTRODUCTION}

Urban space is one of the most significant areas of identity manifestation, culture and civilization of society and city. In addition to urban space is manifestation of the performance relationship between man and space, in terms of political, economic and social has also great value. Today, urban space represents the roots, old ways of thinking and people's lives and also for sociologists, psychologists and historians has utmost value. Urban areas in the past in terms of function and structure have had a good performance for life, while some urban spaces in contemporary period such as squares and streets are not suitable for urban life and evidence suggests that the role of their communication is as the most important function and in some cases their only function and although people in the large cities during the day exist in such places for moving, but because of the types of pollution such as air pollution, noise pollution and congestion, as well as lack of social activities, presence in these spaces for them not only is not pleasant, but they are elusive.

\section{STATEMENT OF PROBLEM}

Public spaces such as streets, squares and urban nodes, today have valuable position in urban planning and design. This is due to the influence of the spaces on social and cultural aspects of cities and thus producing social capital. In the meantime, city squares due to their special nature and their performance in spatial and physical structure of the city as well as the mental and meaningful reproduction of an urban public space are the most effective spaces of a city in the mind of citizens (Pakzad, 2005).

On the other hand, public spaces of cities are places that belong to the public and provide the inherent need for citizens to use the space, community and physical. In the meantime, urban squares in shaping 
the mental image and mentality of the city have a special role and practically show the city's appearance. The evaluation of experience and understanding of the space can be raised as one of the most important criteria of measuring the success or failure of an urban space. Recognizing physical factors affecting the utility of the space can be effective to analyze the current situation, future decisions to enhance the quality of public spaces, its performance and avoid repeating deficiencies in construction of places and urban spaces (Carmona, 2009).

Therefore, this study aimed to investigate the physical problems of Amol's 17 Shahrivar square to using its redesign provides the causes of promoting functional components. So in this regard, the researcher is seeking the answer to this question:

"How can cause to promote functional components of this square using the redesign of square due to physical problems?"

\section{THEORETICAL FOUNDATIONS URBAN SPACE}

Space word in the dictionary of Dehkhoda means "square and field" and in the dictionary of Moein is defined as "wide place, broad realm". Not long the term is considered in the sense of its architecture and urbanism. Space in the field of knowledge in architecture and urbanism means a space that is limited to various forms and has special functions. Urban space is one of the building elements of city space that with the history of a nation is created in different periods, formed and changed. Urban space is outer and public space that urban life occurs in it and is formed of two main components of street and square. A basic condition for an urban space is social interactions in it. From the perspective of Dr. Pakzad five main types of urban space are: entrance, path node, edge, water and stair. The nodes are called to influence centers on the mind of citizens that it may be the place of gathering on the square or at the square the place of segregation. Nodes, including the Local Square, urban, ceremonial and squares and totally nodes are expected for stillness, assembly and integration (Ebrahimi, 2009).

\section{SQUARE}

Square in Persian dictionary of Moein means width of earth, field and area that few streets are connected to it. Square is a dramatic arena for the life of a city and informs from moving, attempt to life and vitality of its citizens. Square identifies city by design and its composition and informs the originality of its inhabitants. This field indicates the strength, creativity, art and perfection of people and indicates the love to life and love to collective aspirations. A brief review of the historical evolution of square from ancient cities so far, suggests that over time square has had an influential role in the set of city organs and has had great effects on the formation and spatial organization of the city to different historical periods. Square as urban space is existed with human presence and significant pause and to a certain intention in relation to population movements and in addition, it reveals the effects of created space of communication, contact and activity of human (Ebrahimi, 2009) Dehkhoda dictionary about the meaning of square, writes: "a broad area that around it placed house or shop" and says: "The word of square in original is Persian and Arabs pluralize it and say squares. With this definition in the past, square was called to any wide, broad place, and without mansion. That's why square was called to big places where people sold livestock, fruits and vegetables, charcoal, straw and like it; This type of squares were commercial squares and to this day, such places have square name, such as fruit and vegetables square. Other square were mainly governmental squares that government institutions were established around it like Arg square of Tehran or Naghsh Jahan Square in Isfahan. Military square which was special for military exercises and residence of militaries around them such as artillery square of Tehran, sports square that would be assigned to sports matches such as horse riding squares or Naghsh Jahan Square that its middle space was used to play polo (Kazemi, 2006)

Different characteristics and definitions can be raised for square that briefly some of them are mentioned below: 
- From the historical perspective and definitions that are derived from the literature, urban square is a space with special historical records, memorials and monuments of the past events that is considered as a common memory for citizens.

- In terms of performance, wide spaces with enclosed area or more or less certain and with a communicative function, social, business, sports, military, or a combination of two or more operations, were called Square (Soltanzadeh, 2006).

- Urban square links with street network and acts like its joints and is considered its pause point (Gharib, 1997).

- Square is a main space in city which social interactions can be established in it and is a key element in creating sustainable urban space (Nazari \& Raziye Beigi, 2011).

- Square is a chance to relax, think and reflect on the visual theme (Schultz, 2002).

Thus, according to the definitions provided, square is a general and usable space for population to carry out various activities, mobility and stop, recall memories, seeing and being seen, ceremonies, sales, holding political rallies such as protests and campaigns and briefly refers to a space that everything can be done at the same time. (Nazari \& Raziye Beigi, 2011).

\section{Type And The Main Function Of Square}

Since the introduction of the concept of square, type and main function of square has been one of the important factors in adjust and mix place of surrounding activities or inside each square. As naturally in a suburban business square that was lack of built space such as square of selling sheep, horse sales, straw sales and etc. took place in open space and each group was in a part of the space, while in an important governmental square, at least in the open space located in front of the government building no less important activities such as retail was not done, as well as rarely happened that the open space used for buying and selling as a local square permanently (Soltanzadeh, 2006).

According to a proposed categorization, squares based on the type of function are divided to public, business, governmental, military, local, sports and communication squares. Different categories of squares are done from other views. Including the classification that Zooker does from squares, it is divided into five categories that include fenced and closed, dominant, nuclear, collective and amorphous squares (Nazari \& Raziye Beigi).

\section{CURRENT STATUS OF SQUARES}

There is a sense from squares that is the same as that is created in the mind of everyone and alike the intersection of several streets that a space in the middle of it created to separate the moving of cars and is formed with the combination of vegetation, pool and fountains and not has a reasonable relationship with human, human movement and significant presence of human. Square is without the presence of human and not has external meaning and human presence in this space not has meaning; neither effective nor safe. Today, almost no aesthetic principle is respected in shaping square. Generally, there is no logic coordination and thought between functions, visual proportions, shapes, and materials of a square. The machine is placed at square most of time and levels belong to human are only to move. Almost not any mental relaxation and physiological induces to human. In Iran, today not be made a square with traditional design and squares that are established have less resemblance to the traditional squares of Iran (Naghizadeh, 2006).

\section{RESEARCH BACKGROUND}

Many studies are conducted in the field of urban spaces and design of such spaces that among them can refer to research of Golkar (2000), entitled "constructive components of quality of urban design", Sheikh Kazem (2006), titled "urban squares (Plaza)", Pourjafar and Sadeghi (2008), titled " the principles dominant on targeted design of viewing axis of urban indicator", Ebrahimi (2009), entitled" Square; undefined spaces of Iranian cities "a review of manner, form making, performance and the 
fate of Iranian square, Asiyabi (2010), in his book "urban squares: from concept to its reality in cities of Iran", Nazari (2011), "Square: a space for social interactions and its design solutions ", Rastbin and colleagues (2012), in a study entitled "correlation between environmental quality and sustainability of urban life in the public arena", Rezazadeh and Mir Heiydar (2012), entitled "design of Mashhad railway square relying on the principles of environment perceptions", center for the study and town planning of Tehran (2013), entitled "study factors affecting the promotion of space quality of squares with the approach of urban design" and Mousavi (2013), in his article titled, "redesign of urban spaces with an emphasis on urban identity, case study: Green Square complex in Bojnoord center" investigated the theoretical foundations of environmental quality and desired public spaces and presented a framework of the criteria of measuring quality of the spaces and required characteristics.

\section{RESEARCH SUB- HYPOTHESES}

1. Redesign rhythm and balance in Amol's 17 Shahrivar square as a physical component causes to promote the functional components in the square.

2. Redesign the principle of static and dynamic in Amol's 17 Shahrivar square as a physical component causes to promote the functional components in the square.

3. Redesign shape and decoration in Amol's 17 Shahrivar square as a physical component causes to promote the functional components in the square.

4. Redesign streets and pedestrian route in Amol's 17 Shahrivar square as a physical component causes to promote the functional components in the square.

5. Improve the physical components causes to promote human activities in Amol's 17 Shahrivar square as functional components.

6. Improve the physical components causes to promote optional activities in Amol's 17 Shahrivar square as functional components.

7. Improve the physical components causes to promote social activities in Amol's 17 Shahrivar square as functional components.

\section{RESEARCH METHODOLOGY}

Considering that the present study pays attention to review and redesign the physical components of Amol's 17 Shahrivar square, it can be said that this research is an applied research objectively and since in the study, predominantly due to the fact that data collection from all the constituent members of a society is time consuming and not affordable in terms of cost and there isn't ability to do research in whole society, researcher from the main population (total) select a sample. So Cochran's formula of unlimited population is used that the sample size of 196 individuals was selected and questionnaire was distributed among them. After the information is collected through a questionnaire, coded and entered into the computer, the present method is conducted using descriptive statistics (frequency table, mean, variance, percentage, charts, etc ...) respondents' demographic (age, gender, education and ...) inferential statistics (correlation, multiple regression to investigate the hypotheses and association between research components, Friedman test is used for ranking items affected in the study) and using SPSS statistical software, data is analyzed.

\section{ANALYSIS OF DATA \\ BINOMIAL TEST RELATED TO VARIABLES}

\section{Statistical hypotheses:}

$$
\text { H0 : C } \leq 3 \quad \text { H1 : C }>3
$$

First hypothesis: the rhythm and balance components 
Table 3. Results of Binomial test of variables

\begin{tabular}{|c|c|c|c|c}
\hline Component & $\begin{array}{c}\text { Observed } \\
\text { percentage }\end{array}$ & Percentage of test & $\begin{array}{c}\text { Significant } \\
\text { level }\end{array}$ & Result \\
\hline $\begin{array}{c}\text { Rhythm } \\
\text { and } \\
\text { balance }\end{array}$ & 0.50 & 0.65 & 0.027 & Undesirable \\
\hline
\end{tabular}

If the observed percentage is less than the percentage of test, so to determine approve or reject the null hypothesis should refer to significance level $(\mathrm{Sig}=0.00$ ), and if the significant level is less than 0.05 , so the null hypothesis is rejected and hypotheses one will be approved. So in the first hypotheses, observed percentage $(0.50)$ is smaller than the percentage of test $(0.65)$ therefore the discussed components (rhythm and balance) are at undesirable position.

Table 4. Results of Friedman test for ranking the items

\begin{tabular}{|c|c|c|c|c|c}
\hline Line & Item & $\begin{array}{c}\text { Significant } \\
\text { level }\end{array}$ & $\begin{array}{c}\text { Mean of } \\
\text { item }\end{array}$ & $\begin{array}{c}\text { Rate of } \\
\text { item }\end{array}$ & Result \\
\hline A1 & $\begin{array}{c}\text { Coordination of buildings and } \\
\text { monuments around square in } \\
\text { terms of shape and appearance }\end{array}$ & 0.000 & 1.87 & Second & Undesirable \\
\hline A2 & $\begin{array}{c}\text { Different classes of buildings } \\
\text { around the square with each other } \\
\text { (skyline) }\end{array}$ & 0.000 & 2.35 & First & Undesirable \\
\hline A3 & $\begin{array}{c}\text { The visual beauty of the } \\
\text { buildings and surrounding } \\
\text { buildings }\end{array}$ & 0.000 & 1.78 & Third & Undesirable \\
\hline
\end{tabular}

Also according to the table above, the results indicate that respondents' views of sample about the items of rhythm and balance variable, at least in one case are not the same and the items of A2, A1 and $\mathrm{A} 3$, respectively, with mean of $2.35,1.87$ and 1.78 have first rate to third that every three items are at an undesirable position.

The second hypothesis: static and dynamic components

Table 5. Results of Binomial test of variables

\begin{tabular}{|c|c|c|c|c}
\hline Component & $\begin{array}{c}\text { Observed } \\
\text { percentage }\end{array}$ & Percentage of test & $\begin{array}{c}\text { Significant } \\
\text { level }\end{array}$ & Result \\
\hline $\begin{array}{c}\text { static and } \\
\text { dynamic }\end{array}$ & 0.50 & 0.62 & 0.092 & Undesirable \\
\hline
\end{tabular}

If the observed percentage is less than the percentage of test, so to determine approve or reject the null hypothesis should refer to significance level ( $\mathrm{Sig}=0.00$ ), and if the significant level is less than 0.05 , so the null hypothesis is rejected and hypotheses one will be approved. So in the second hypotheses, observed percentage $(0.50)$ is smaller than the percentage of test $(0.65)$ therefore the discussed components (static and dynamic) are at undesirable position.

Table 6. Results of Friedman test for ranking the items

\begin{tabular}{|c|c|c|c|c|c}
\hline Line & Item & $\begin{array}{c}\text { Significant } \\
\text { level }\end{array}$ & $\begin{array}{c}\text { Mean of } \\
\text { item }\end{array}$ & $\begin{array}{c}\text { Rate of } \\
\text { item }\end{array}$ & Result \\
\hline A4 & $\begin{array}{c}\text { enough parking around the } \\
\text { square }\end{array}$ & 0.000 & 1.53 & Third & Undesirable \\
\hline A5 & $\begin{array}{c}\text { Ease of crossing people as } \\
\text { pedestrian }\end{array}$ & 0.000 & 1.77 & First & Undesirable \\
\hline A6 & traffic in the streets connected to & 0.000 & 2.70 & Third & Undesirable \\
\hline
\end{tabular}




\begin{tabular}{|l|l|l|l|l|l}
\hline & square & & & & \\
\hline
\end{tabular}

Also according to the table above, the results indicate that respondents' views of sample about the items of static and dynamic variable, at least in one case are not the same and the items of A4, A5 and A6, respectively, with mean of 2.70, 1.77 and 1.53 have first rate to third that item A6 is in desirable position and items A4 and A5 are at an undesirable position.

The third hypothesis: shape and decorations components

Table 7. Results of Binomial test of variables

\begin{tabular}{|c|c|c|c|c}
\hline Component & $\begin{array}{c}\text { Observed } \\
\text { percentage }\end{array}$ & Percentage of test & $\begin{array}{c}\text { Significant } \\
\text { level }\end{array}$ & Result \\
\hline $\begin{array}{c}\text { shape and } \\
\text { decorations }\end{array}$ & 0.50 & 0.75 & 0.000 & Undesirable \\
\hline
\end{tabular}

If the observed percentage is less than the percentage of test, so to determine approve or reject the null hypothesis should refer to significance level $(\mathrm{Sig}=0.00)$, and if the significant level is less than 0.05 , so the null hypothesis is rejected and hypotheses one will be approved. So in the third hypotheses, observed percentage $(0.50)$ is smaller than the percentage of test $(0.75)$ therefore the discussed components (shape and decorations) are at undesirable position.

Table 8. Results of Friedman test for ranking the items

\begin{tabular}{|c|c|c|c|c|c}
\hline Line & Item & $\begin{array}{c}\text { Significant } \\
\text { level }\end{array}$ & $\begin{array}{c}\text { Mean of } \\
\text { item }\end{array}$ & $\begin{array}{c}\text { Rate of } \\
\text { item }\end{array}$ & Result \\
\hline A7 & Lighting utility in the square & 0.000 & 2.41 & First & Undesirable \\
\hline A8 & $\begin{array}{c}\text { Quality of flooring and floors of } \\
\text { square routes }\end{array}$ & 0.000 & 2.04 & Second & Undesirable \\
\hline A9 & Spaces for rest and recreation & 0.000 & 1.55 & Third & Undesirable \\
\hline
\end{tabular}

Also according to the table above, the results indicate that respondents' views of sample about the items of shape and decorations variable, at least in one case are not the same and the items of A7, A8 and A9, respectively, with mean of 2.41, 2.04 and 1.55 have first rate to third that all three items are at an undesirable position.

The fourth hypothesis: streets and pedestrian route components

Table 9. Results of Binomial test of variables

\begin{tabular}{|c|c|c|c|c}
\hline Component & $\begin{array}{c}\text { Observed } \\
\text { percentage }\end{array}$ & Percentage of test & $\begin{array}{c}\text { Significant } \\
\text { level }\end{array}$ & Result \\
\hline $\begin{array}{c}\text { streets and } \\
\text { pedestrian } \\
\text { route }\end{array}$ & 0.50 & 0.70 & 0.003 & Undesirable \\
\hline
\end{tabular}

If the observed percentage is less than the percentage of test, so to determine approve or reject the null hypothesis should refer to significance level $(\mathrm{Sig}=0.00)$, and if the significant level is less than 0.05 , so the null hypothesis is rejected and hypotheses one will be approved. So in the fourth hypotheses, observed percentage $(0.50)$ is smaller than the percentage of test $(0.70)$ therefore the discussed components (streets and pedestrian route) are at undesirable position.

Table 10. Results of Friedman test for ranking the items

\begin{tabular}{|c|c|c|c|c|c}
\hline Line & Item & $\begin{array}{c}\text { Significant } \\
\text { level }\end{array}$ & $\begin{array}{c}\text { Mean of } \\
\text { item }\end{array}$ & $\begin{array}{c}\text { Rate of } \\
\text { item }\end{array}$ & Result \\
\hline
\end{tabular}


The Turkish Online Journal of Design, Art and Communication - TOJDAC July 2016 Special Edition

\begin{tabular}{|c|c|c|c|c|c}
\hline A10 & Fit the width of sidewalks & 0.000 & 2.42 & Second & Undesirable \\
\hline A11 & $\begin{array}{c}\text { Traffic of pedestrian in sidewalks } \\
\text { around square }\end{array}$ & 0.000 & 3.27 & First & Undesirable \\
\hline A12 & $\begin{array}{c}\text { Decorative elements and green } \\
\text { space on sidewalks }\end{array}$ & 0.000 & 2.13 & Fourth & Undesirable \\
\hline A 13 & $\begin{array}{c}\text { Fitness of lines and pedestrian } \\
\text { bridges }\end{array}$ & 0.000 & 2.18 & Third & Undesirable \\
\hline
\end{tabular}

Also according to the table above, the results indicate that respondents' views of sample about the items of streets and pedestrian route variable, at least in one case are not the same and the items of A11, A10 and A13, A12 respectively, with mean of 3.27, 2.42, 2.18 and 2.13 have first rate to fourth that item A11 is in desirable position and other items are at an undesirable position. The fifth hypothesis: human activities components.

Table 11. Results of Binomial test of variables

\begin{tabular}{|c|c|c|c|c}
\hline Component & $\begin{array}{c}\text { Observed } \\
\text { percentage }\end{array}$ & Percentage of test & $\begin{array}{c}\text { Significant } \\
\text { level }\end{array}$ & Result \\
\hline $\begin{array}{c}\text { human } \\
\text { activities }\end{array}$ & 0.50 & 0.75 & 0.000 & Undesirable \\
\hline
\end{tabular}

If the observed percentage is less than the percentage of test, so to determine approve or reject the null hypothesis should refer to significance level $(\mathrm{Sig}=0.00$ ), and if the significant level is less than 0.05, so the null hypothesis is rejected and hypotheses one will be approved. So in the fifth hypotheses, observed percentage $(0.50)$ is smaller than the percentage of test $(0.75)$ therefore the discussed components (human activities) are at undesirable position.

Table 12. Results of Friedman test for ranking the items

\begin{tabular}{|c|c|c|c|c|c}
\hline Line & Item & $\begin{array}{c}\text { Significant } \\
\text { level }\end{array}$ & $\begin{array}{c}\text { Mean of } \\
\text { item }\end{array}$ & $\begin{array}{c}\text { Rate of } \\
\text { item }\end{array}$ & Result \\
\hline A14 & $\begin{array}{c}\text { The availability of climatic } \\
\text { comfort on the field (including } \\
\text { embedded drawings in rainy and } \\
\text { sunny) }\end{array}$ & 0.000 & 1.55 & Third & Undesirable \\
\hline A15 & $\begin{array}{c}\text { Feel safe when crossing the } \\
\text { square }\end{array}$ & 0.000 & 2.09 & Second & Undesirable \\
\hline A16 & $\begin{array}{c}\text { Supply needs and daily } \\
\text { necessities people }\end{array}$ & 0.000 & 2.36 & First & Undesirable \\
& & & & \\
\hline
\end{tabular}

Also according to the table above, the results indicate that respondents' views of sample about the items of human activities variable, at least in one case are not the same and the items of A16, A15 and A14, respectively, with mean of 2.36, 2.09 and 1.55 have first rate to third that all three items are at an undesirable position.

The sixth hypothesis: Optional activities components

Table 13. Results of Binomial test of variables 


\begin{tabular}{|c|c|c|c|c}
\hline Component & $\begin{array}{c}\text { Observed } \\
\text { percentage }\end{array}$ & Percentage of test & $\begin{array}{c}\text { Significant } \\
\text { level }\end{array}$ & Result \\
\hline $\begin{array}{c}\text { Optional } \\
\text { activities }\end{array}$ & 0.50 & 0.82 & 0.000 & Undesirable \\
\hline
\end{tabular}

If the observed percentage is less than the percentage of test, so to determine approve or reject the null hypothesis should refer to significance level ( $\mathrm{Sig}=0.00$ ), and if the significant level is less than 0.05, so the null hypothesis is rejected and hypotheses one will be approved. So in the sixth hypotheses, observed percentage $(0.50)$ is smaller than the percentage of test $(0.82)$ therefore the discussed components (optional activities) are at undesirable position.

Table 14. Results of Friedman test for ranking the items

\begin{tabular}{|c|c|c|c|c|c}
\hline Line & Item & $\begin{array}{c}\text { Significant } \\
\text { level }\end{array}$ & $\begin{array}{c}\text { Mean of } \\
\text { item }\end{array}$ & $\begin{array}{c}\text { Rate of } \\
\text { item }\end{array}$ & Result \\
\hline A17 & $\begin{array}{c}\text { Refer to the square for recreation } \\
\text { and leisure }\end{array}$ & 0.000 & 1.76 & Third & Undesirable \\
\hline A18 & $\begin{array}{c}\text { Refer to the square to meet with } \\
\text { friends }\end{array}$ & 0.000 & 2.09 & Second & Undesirable \\
\hline A19 & $\begin{array}{c}\text { A sense of satisfaction due to the } \\
\text { presence in the square }\end{array}$ & 0.000 & 2.15 & First & Undesirable \\
\hline
\end{tabular}

Also according to the table above, the results indicate that respondents' views of sample about the items of optional activities variable, at least in one case are not the same and the items of A19, A18 and A17, respectively, with mean of 2.15, 2.09 and 1.76 have first rate to third that all three items are at an undesirable position.

The seventh hypothesis: social activities components

Table 15. Results of Binomial test of variables

\begin{tabular}{|c|c|c|c|c}
\hline Component & $\begin{array}{c}\text { Observed } \\
\text { percentage }\end{array}$ & Percentage of test & $\begin{array}{c}\text { Significant } \\
\text { level }\end{array}$ & Result \\
\hline $\begin{array}{c}\text { social } \\
\text { activities }\end{array}$ & 0.50 & 0.88 & 0.000 & Undesirable \\
\hline
\end{tabular}

If the observed percentage is less than the percentage of test, so to determine approve or reject the null hypothesis should refer to significance level ( $\mathrm{Sig}=0.00$ ), and if the significant level is less than 0.05, so the null hypothesis is rejected and hypotheses one will be approved. So in the seventh hypotheses, observed percentage $(0.50)$ is smaller than the percentage of test $(0.88)$ therefore the discussed components (social activities) are at undesirable position.

Table 16. Results of Friedman test for ranking the items

\begin{tabular}{|c|c|c|c|c|c}
\hline Line & Item & $\begin{array}{c}\text { Significant } \\
\text { level }\end{array}$ & $\begin{array}{c}\text { Mean of } \\
\text { item }\end{array}$ & $\begin{array}{c}\text { Rate of } \\
\text { item }\end{array}$ & Result \\
\hline A20 & $\begin{array}{c}\text { Spaces for meeting and } \\
\text { interacting with the community }\end{array}$ & 0.000 & 1.48 & Second & Undesirable \\
\hline A21 & $\begin{array}{c}\text { Space for celebration and } \\
\text { mourning in the square }\end{array}$ & 0.000 & 1.52 & First & Undesirable \\
\hline
\end{tabular}


Also according to the table above, the results indicate that respondents' views of sample about the items of social activities variable, at least in one case are not the same and the items of A21, A20, respectively, with mean of 1.52, 1.48 have first and second rate that both two items are at an undesirable position.

\section{CONCLUSION}

If the observed percentage is less than the percentage of test, so to determine approve or reject the null hypothesis should refer to significance level $(\mathrm{Sig}=0.00)$, and if the significant level is less than 0.05 , so the null hypothesis is rejected and hypotheses one will be approved. In all hypotheses (rhythm and balance, static and dynamic, shape and decoration, streets and pedestrian route, human activities, optional activities and social activities) are in an undesirable position. The results indicate that the sample respondents' views about the items of the research variables (rhythm and balance, static and dynamic, shape and decoration, streets and pedestrian route, human activities, optional activities and social activities) from a total of 21 items, except items of A6 and A11 which have a desirable position, other items are in an undesirable position.

\section{OFFERS}

1. Due to the lack of proper shape and significant decorations in the meantime, design green spaces with perfect lighting can be acted.

2. By monitoring and developing a plan for controlling construction of buildings with high density can control the coordination of skyline of area or by monitoring the facades and using Iranian plans generally prevent the lack of coordination of them with the context of the area.

3 . By planting trees and designing green space in the streets and avenues in the square can emit it from uniformity and add to its visual beauty.

4. By surveys conducted, it was found that pedestrians and streets not have good floors that by rebuilding the floors and use good quality materials can provide comfort of people and promote visual quality of this area.

5. Given that urban furniture of this range is very low and in some cases is very weak, it can be added to plurality, diversity and beauty of these elements.

\section{REFERENCES}

Asiyabi, M. (2010), urban squares: from concept to its reality in cities of Iran, Hele publications, Tehran.

Ebrahimi, Mohammad Hassan (2009), Square: undefined spaces of Iranian cities, Journal of identity of the city, third year, Issue 4.

Pakzad, Jahan (2005), guide to design urban spaces in Iran, Tarh and Nashr Payam Sima publishing, Tehran.

Pourjafar, MR and Sadeghi, A. (2008), the principles dominant on the targeted design of viewing axes of urban indicator, publication of the identity of the city, Issue 3.

Rezazadeh, R. and Mir Heidar, S. (2012), design Mashhad railway square relying on the principles of environmental perceptions, Journal of the Association of Iranian Architecture and urbanism, Issue 4.

Rastbin, Sajed and Jafari, Yasser and Daram, Yasaman and Moazezi, Amir Mohammad (2012), the correlation between environmental qualities and sustainability of urban life in the public arena, journal of Bagh Nazar, Issue 21.

Soltanzadeh, H. (2006), the urban space in the historical contexts of Iran, Cultural Research Bureau in Tehran.

Gharib, F. (1997), Urban squares, Fine Arts Magazine, Issue 2.

Schultz, Norberg (2002), the concept of residence, translated by Mahmoud Yar Ahmadi, Agah publications, Tehran.

Sheikh Kazem, MR (2006), Urban Squares (Plaza), Conference on Civil students across the country, Shahid Bahonar University of Kerman.

Golkar, K. (2000), constructive components of urban design quality, Journal of Safe, NO (3).

Carmona, Matthew (2009), public places, urban spaces, translator: Fariba Gharaiy and colleagues, University of Art publications, Tehran. 
Planning \& Research Center in Tehran (2013), investigating the factors affecting promoting the spatial quality of squares, with approach of urban design, department of studies and planning of infrastructure affairs and comprehensive design, management of studies and architectural planning, urbanism and affairs of crisis.

Mousavi, M. (2013), redesign urban spaces with emphasis on urban identity, Case Study: Green Square in the center of Bojnoord, the first national conference on sustainable building, Mashhad.

Nazari, Selda and Rezabeigi, R. (2011), Square: a space for the development of social interactions and its design solutions, the Third National Conference on Urban Development.

Naghizadeh, M. (2006), Reflection on the process of reforming square in Iranian cities, Journal of Fine Arts, Issue 25. 